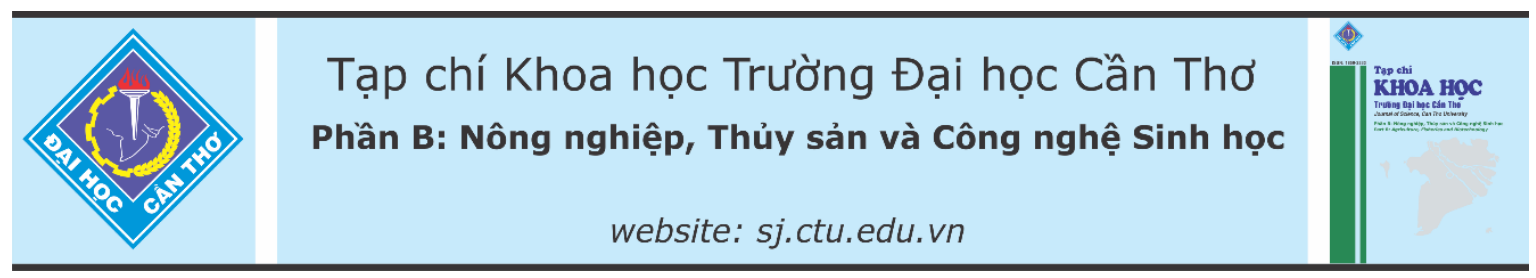

DOI:10.22144/ctu.jvn.2021.151

\title{
NGHIÊN CỨU ÚNG DỤNG Hệ THỐNG NUÔI CÂYY NGẬP CHİM TẠM THOÒI TRONG NHÂN GIỐNG in vitro CÂY HOA LILY (Lilium spp.)
}

\author{
Phạm Thị Thùy Trang* \\ Khoa Kỹ thuật - Nông nghiệp, Phân hiệu Đại học Đà Nã̃ng tại Kon Tum \\ *Nguò̀i chịu trách nhiệm về bài viết: Phạm Thị Thùy Trang (email: ptttrang@kontum.udn.vn)
}

\section{Thông tin chung:}

Ngày nhận bài: 09/04/2021

Ngày nhận bài sưa: 12/06/2021

Ngày duyệt đăng: 29/10/2021

\section{Title:}

A study on applying temporary immersion system to in vitro micropropagation of Lilium spp.

\section{Tù khóa:}

Hệ thống ngập chim tạm thời, Lilium spp., nhân giống in vitro, Plantima

\section{Keywords:}

in vitro propagation, Lilium spp., Plantima, temporary immersion system

\begin{abstract}
Lily (Lilium spp.) is an important plant with high economic value, grown in many countries around the world. However, bulbs of lily produced in Vietnam are not enough to meet domestic demand, most flower bulbs are imported from abroad. In this study, in vitro plant regeneration and micropropagation of lilies were established on temporary immersion system, using the bulb scales as the starting material. Surface sterilization with $\mathrm{HgCl}_{2} \quad 1 \%$ in 9 minutes, the fungus-free material is cultured on temporary immersion system using MS medium supplemented with sucrose $30 \mathrm{~g} / \mathrm{L}, B A 2 \mathrm{mg} / \mathrm{L}$, NAA $0.5 \mathrm{mg} / \mathrm{L}$. The highest bulblet regeneration is $83.89 \%$. The experiment results show that the highest number of bulbs (3.72) per explant was reached at 6-hour interval of 5minute submersion while the number of roots per an explant is the highest (4.52 roots), submerged for 3 minutes with the cycle of every 6 hours. As a result, lilies can grow and develop better on temporary immersion system.
\end{abstract}

\section{TÓM TẮT}

Lily (Lilium spp.) là cây hoa quan trọng, có giá trị kinh tế cao, được trồng ơ nhiều nước trên thế giới. Tuy nhiên, giống hoa lily sản xuất ở Việt Nam chura đủ đáp úng nhu cầu trong nước, đa số giống hoa được nhập khẩu tù nuoớc ngoài. Trong nghiên cứu này, hoa lily được nhân giống in vitro thành công trên hệ thống ngập chìm tạm thời, sử dụng vật liệu ban đầu là mẫu vảy củ. Vật liệu được khư trùng trong 9 phút bằng dung dịch $\mathrm{HgCl}_{2}$ 1\%o. Vật liệu sạch nấm khuẩn được nuôi cấy trên hệ thống ngập chìm chứa môi trường $M S$ có bổ sung đường $30 \mathrm{~g} / \mathrm{L} B A 2 \mathrm{mg} / \mathrm{L}, N A A$ 0,5 $\mathrm{mg} / \mathrm{L}$. Khả năng tái sinh chồi cao nhẩt 83,89\%. Kết quả nghiên cứu cho thấy số củ mới được tạo thành trên một mẫu là cao nhất (3,72 củ), thời gian ngập chìm 5 phút với chu kỳ ngập 6 giờ. Số rễ hình thành trên một mẫu là cao nhất (4,52 rễ), thời gian ngập chìm 3 phút với chu kỳ ngập 6 giờ. Kết quả cho thấy hoa lily sinh trương và phát triển tốt trên hệ thống ngập chim tam thời.

\section{GIỚI THIỆ}

Hoa lily được phát hiện từ khoảng năm 1750 trước Công nguyên, lily toát lên vẻ đẹp tinh khiết, hương thơm tao nhã. Hầu hết các loài lily được phân bố ở châu Á, Bắc Mỹ và châu Âu, lily có rất nhiều loài khác nhau với những dạng hoa, màu sắc hoa rất phong phú và hấp dẫn. Ở Việt Nam, hoa lily được 
xếp vào nhóm hoa cao cấp và được tiêu dùng mạnh trong 5 năm trở lại đây, hàng năm nhu cầu tiêu dùng nội địa khoảng 20 triệu cành trong khi đó chúng ta mới chỉ sản xuất được 12 triệu cành, khối lượng còn lại phải nhập khẩu từ các nước, vùng lãnh thổ khác như Đài Loan, Trung Quốc, Hà Lan (Đặng Văn Đông và ctv., 2010).

Nhân giống hoa lily bằng kỹ thuật nuôi cấy mô tế bào thực vật là phương pháp nhân giống hiện đại và hiệu quả nhất để tạo củ giống chất lượng cao, đồng đều, sạch bệnh với số lượng lớn, ổn định, đồng nhất về mặt di truyền, đáp ứng mục đích sản xuất củ trên quy mô thương mại ở nhiều giống lily (Nguyễn Văn Tỉnh và ctv.,2013). Tuy nhiên, việc cấy truyền không thể tự động hóa do đó không mang lại hiệu suất và giá trị kinh tế cao. Phương pháp nuôi cấy trên môi trường thạch, mẫu cấy dễ nhiễm vi khuẩn, nấm, tỷ lệ cây non sống sót thấp, tiêu tốn một lượng lớn cơ chất, nhân công, thiết bị,... Nhân giống trong môi trường lỏng mô cấy bị nhận chìm xuống nước gây thiếu khí vì vậy phương pháp này đã không được sử dụng phổ biến (Vidal, 2015). Hệ thống nuôi cấy ngập chìm tạm thời (temporary immersion system: TIS) ra đời và phát triển vào cuối năm 1990 dự báo một mốc quan trọng trong vi nhân giống bán tự động trong nông nghiệp và bảo tồn. Sự cải tiến về mặt cấu tạo và nguyên tắc hoạt động của hệ thống TIS mang lại hiệu quả vi nhân giống ngày càng cao. Hệ thống TIS không những tận dụng được các ưu điểm của nuôi cấy lỏng và nuôi cấy trên thạch mà còn hạn chế được những nhược điểm của hai hệ thống nuôi cấy trên giúp tạo ra môi trường nuôi cấy thoáng khí, cây con khỏe mạnh, tỉ lệ sống cao, giảm chi phí nhân công, giảm chi phí môi trường do sử dụng ít môi trường trên một mẫu cấy và không sử dụng thạch, hệ số nhân gia tăng nhiều lần so với khi nhân giống trên hệ thống nuôi cấy thông thường (Paula, 2012). Kết quả nghiên cứu nuôi cấy cây Zantedeschia aethiopica và Anthurium andraeanum trên hệ thống TIS có tần suất ngập 3 phút trong chu kỳ 16 giờ, nhiệt độ $25^{\circ} \mathrm{C}$, sau 20 ngày tiến hành kiểm tra cho thấy cây sinh trưởng nhanh, phát triển tốt, hạn chế tạo mô sẹo. Đây là nghiên cứu tiềm năng cho việc sản xuất cây giống invitro ở quy mô công nghiệp (Barbara \& Marco, 2005).

Việt Nam cũng như nhiều nước khác trên thế giới sản xuất củ giống hoa lily chưa đảm bảo tiêu chuẩn, nguồn giống chủ yếu phải nhập khẩu từ nước ngoài do đó giá thành cao, nhà vườn không chủ động được giống trồng trọt. Vì vậy, việc xây dựng hệ thống sản xuất giống sạch bệnh cung cấp cho sản xuất là một yêu cầu cấp thiết. Nghiên cứu ứng dụng hệ thống nuôi cấy ngập chìm tạm thời trong nhân giống cây hoa lily trong điều kiện in vitro nhằm tìm ra các thông số tối ưu cho quá trình sản xuất, từ đó xây dựng quy trình nuôi cấy cây hoa lily ở quy mô sản xuất công nghiệp. Kết quả nghiên cứu sẽ mở ra một hướng đi mới, đầy tiềm năng cho ngành nhân giống in vitro cây hoa lily đáp ứng nhu cầu thị trường trong nước.

\section{VẠT LIỆU VÀ PHƯƠNG PHÁP NGHHỀ CÚU}

\subsection{Nguyên liệu, hóa chất}

Nguồn mẫu được sử dụng trong nghiên cứu là giống hoa lily Belladonna, thuộc nhóm OT Hybrid (lily thom) có nguồn gốc từ Hà Lan. Những cây khỏe mạnh, không sâu bệnh được chọn, bảo quản và đem về phòng thí nghiệm làm vật liệu nuôi cấy.

Hóa chất pha môi trường khoáng $\mathrm{MS}$ (Murashige \& Skoog, 1962), chất điều hòa sinh trưởng benzyladenine (BA) và naphthaleneacetic acid (NAA), saccharose độ tinh khiết 99,99\% xuất xứ Hà Lan.

\section{2. Điều kiện, thiết bị}

Thí nghiệm thực hiện ở điều kiện nhiệt độ $25 \pm$ $2^{\circ} \mathrm{C}$, độ ẩm $80 \div 85 \%$, cường độ ánh sáng 2000 2500 lux, thời gian chiếu sáng 12 giờ/ngày. Các thiết bị thông dụng như: cân phân tích có tải trọng cân $0,0001 \div 250 \mathrm{~g}$, độ chính xác của cân là $0,0001 \mathrm{~g}$ máy đo $\mathrm{pH}$ để bàn, máy khuấy từ, máy cất nước 1 lần, nồi hấp khử trùng, tủ lạnh, tủ cấy vi sinh, pipet, ống đong, cốc thủy tinh, bình định mức, bình tam giác, dụng cụ giải phẫu mô gồm: dao, kéo, kẹp, đèn cồn, giá để dụng cụ̣, khay đựng mẫu cấy, giấy lót khử trùng.

Hai hệ thống ngập chìm tạm thời do công ty Atech BioScientific Đài Loan sản xuất, có cấu tạo gồm 24 bình Plantima, 2 bơm nén khí điều khiển tự động, 4 chai đựng dung dịch $\mathrm{CuSO}_{4}, 48$ đầu lọc vô trùng $0,45 \mu \mathrm{m}$, dây silicon. Phương pháp lắp đặt, vận hành hệ thống TIS cụ thể như sau:

\section{Phuoong pháp lắp đặt}

Bước 1: Lắp các bộ phận của bình Plantima như Hình 1

Bước 2: Chuẩn bị môi trường nuôi cấy, dung dịch đồng sunphat thể tích $700 \mathrm{ml} / \mathrm{chai}$, các ống nối từ bơm đến bình Plantima, hệ thống đèn chiếu sáng. 


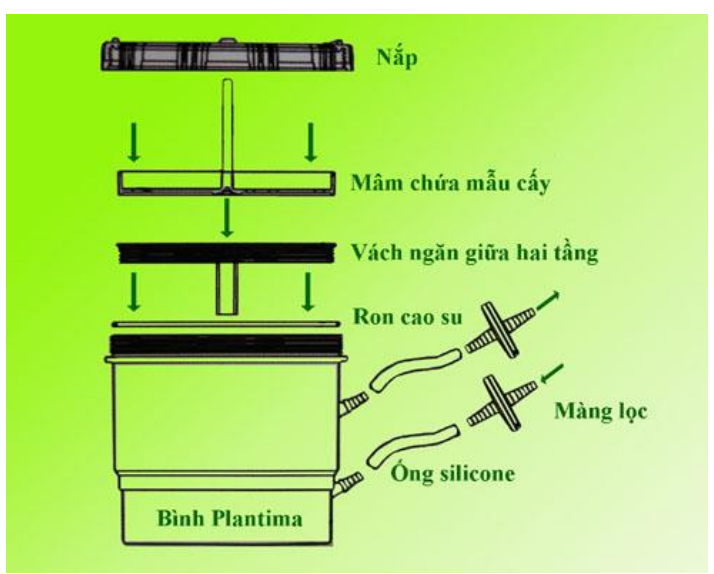

Hình 1. Cấu tạo bình Plantima

Bước 3: Lắp bình Plantima với ống dẫn khí, hệ thống bơm, gắn ống dẫn khí từ ngõ khí ra đến hệ thống phân phối khí như Hình 2.

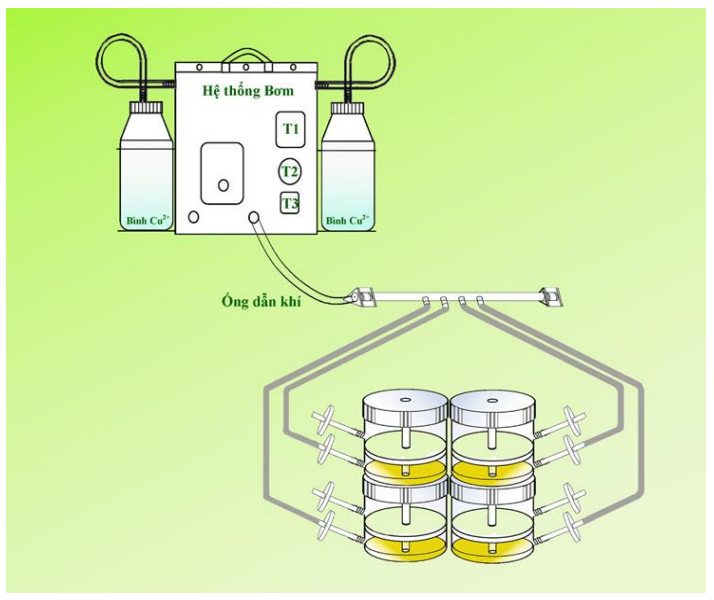

Hình 2. Hệ thống ngập chìm tạm thời

\section{Quy trình vận hành hệ thống TIS:}

Hệ thống TIS được lắp với nguồn điện $220 \mathrm{~V} / 60 \mathrm{~Hz}$, cài đặt bộ hẹn giờ chính: $\mathrm{ON}$ : chu kỳ hoạt động của bơm 0-99 phút (khoảng thời gian $\mathrm{A}$ ), OFF: chu kỳ nghỉ 0-99 phút (khoảng thời gian $\mathrm{B}$ ), cài đặt thời gian chờ (khoảng thời gian $\mathrm{C}$ ) để giữ môi trường sau khi bơm khí. Sau khi đã lắp các thành phần của hệ thống như hướng dẫn, chu kỳ ngập chìm cho hệ thống được tiến hành cài đặt. Có 3 thông số cần được cài đặt lần lượt là thời gian $\mathrm{A}, \mathrm{B}$ và $\mathrm{C}$ :

- A: Thời gian bơm được kích hoạt, khí được nén vào ngăn chứa môi trường tạo được áp suất đẩy môi trường lỏng dâng lên ngăn chứa mẫu.

- B: Thời gian bơm ngừng hoạt động, van khí mở ra giúp khí ở ngăn chứa môi trường thoát ra ngoài, môi trường từ ngăn chứa mẫu theo trọng lực chảy xuống ngăn dưới như ban đầu. Khi thời gian $\mathrm{B}$ kết thúc, hệ thống lặp lại chu kỳ như đã cài đặt.

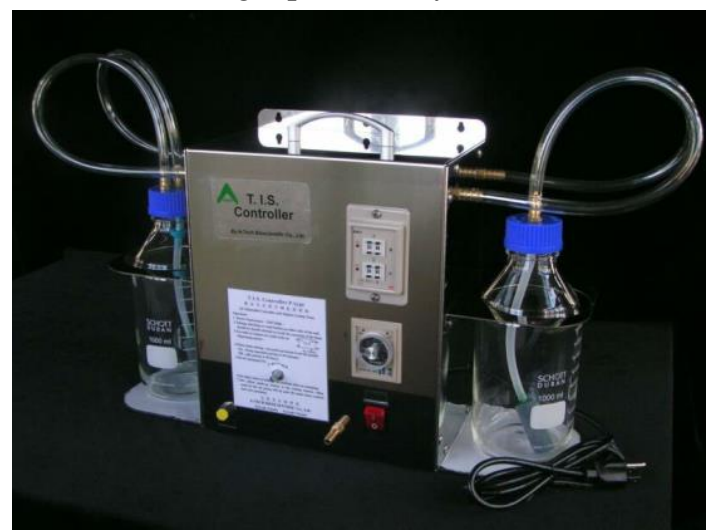

Hình 3. Cài đặt các thông số kỹ thuật

- C: Thời gian bơm ngừng hoạt động, van xả khí vẫn đóng giúp áp suất được duy trì, mẫu ngập trong môi trường mà không có sự sục khí.

Nút màu vàng thử bơm, khi ấn vào bơm sẽ bỏ qua bộ hẹn giờ chính và khởi động bơm. Môi trường được bơm lên ngập mẫu, lắc nhẹ bình Plantima đảm bảo tất cả các mẫu đều được tiếp xúc với môi trường.

Nút kim loại trên bảng hướng dẫn được sử dụng để điều chỉnh tốc độ bơm khí, điều chỉnh mũi tên từ $\mathrm{L} \rightarrow \mathrm{H}$. Khả năng tạo áp suất được kiểm tra để đảm bảo môi trường dâng từ ngăn dưới lên ngăn trên ở tất cả các bình Plantima. Hệ thống được vận hành thử với môi trường lỏng thay bằng $250 \mathrm{ml}$ nước cất/bình trong điều kiện vô trùng, theo dõi hệ thống vận hành đúng như lập trình, việc vận hành hệ thống đã thành công.

\subsection{Phương pháp bố trí thí nghiệm}

Thí nghiệm áp dụng phương pháp nuôi cấy mô tế bào thực vật, sử dụng môi trường MS (Murashige \& Shoog,1962), saccarose, nước dừa, than hoạt tính, chất điều tiết sinh trưởng, $\mathrm{pH}$ môi trường là 5,78 . Môi trường nuôi cấy hấp khử trùng ở $121^{\circ} \mathrm{C}$ trong 20 phút ở áp suất $1 \mathrm{~atm}$. Thí nghiệm bố trí hoàn toàn ngẫu nhiên, 3 lần nhắc lại, quan sát định kỳ 2 tuần/lần. Các chỉ tiêu theo dõi được tiến hành theo phương pháp nghiên cứu nông sinh học như: tỷ lệ mẫu sạch, tỷ lệ sống, đường hướng phát sinh hình thái, số lá, số chồi, chiều dài chồi, số củ, số rễ, chiều dài rễ.

\subsubsection{Khảo sát thời gian khử trùng mẫu}

Sử dụng củ giống đã phá ngủ để tách vảy, tách bỏ vảy củ bị dập nát, thối hỏng, chỉ sử dụng vảy củ 
sạch, không bị tổn thương ở bên trong làm vật liệu nuôi cấy.

Xử lý mẫu bên ngoài tủ cấy: Mẫu được rửa sạch dưới vòi nước máy, sau đó mẫu được ngâm trong nước xà phòng loãng 5 phút, mẫu được rửa lại bằng nước sạch. Tiếp đó, thuốc kháng sinh Streptomicine $1 \%$ được dùng lắc mẫu trong 45 phút, sau đó sửa sạch bằng nước cất ion.

Xử lý mẫu bên trong tủ cấy: Mẫu đưa vào tủ cấy rửa lại bằng nước hấp vô trùng 4-5 lần, mẫu được lắc bằng cồn $70^{\circ}$ với thời gian 30 giây, sau đó rửa sạch bằng nước cất, tiếp theo mẫu được xử lý bằng dung dịch $\mathrm{HgCl}_{2} 1 \%$ với các khoảng thời gian khác nhau ( 7 phút, 9 phút, 11 phút, 13 phút), sau đó rửa lại bằng nước cất vô trùng. Mẫu được lắc bằng dung dịch $\mathrm{HgCl}_{2} 1 \%$ lần 2 trong thời gian 1 phút, rửa sạch bằng nước cất vô trùng. Mẫu sau khi khử trùng được cấy vào môi trường MS (Murashige \& Skoog, 1962) chứa saccharose $30 \mathrm{~g} / \mathrm{L}$, không chứa chất điều hòa sinh trưởng, thí nghiệm lặp 3 lần với 12 nghiệm thức, sau 2 tuần nuôi cấy, quan sát và ghi nhận chỉ tiêu tỷ lệ mẫu sống, tỷ lệ mẫu chết, tỷ lệ mẫu nhiễm ở các nghiệm thức.

\subsubsection{Khảo sát ảnh hưởng của nồng độ $B A$ đến khả năng tái sinh chồi tù vảy củ}

Vảy sạch nấm khuẩn được cấy vào hệ thống ngập chìm tạm thời chứa môi trường $\mathrm{MS}$ có bổ sung saccharose: $30 \mathrm{~g} / \mathrm{L}$, nước dừa: $100 \mathrm{ml} / \mathrm{L}$, than hoạt tính: $0,5 \mathrm{~g} / \mathrm{L}, \mathrm{BA}(1-2,5 \mathrm{mg} / \mathrm{L})$, NAA $0,5 \mathrm{mg} / \mathrm{L}$, tần suất ngập 3 phút trong chu kỳ 6 giờ, nghiên cứu khả năng tái sinh in vitro ở các nồng độ $\mathrm{BA}$ khác nhau $(1,0 \mathrm{mg} / \mathrm{L}, 1,5 \mathrm{mg} / \mathrm{L}, 2,0 \mathrm{mg} / \mathrm{L}$ và $2,5 \mathrm{mg} / \mathrm{L})$, thí nghiệm lặp 3 lần với 12 nghiệm thức, sau 8 tuần nuôi cấy quan sát và ghi nhận chỉ tiêu tỷ lệ tái sinh chồi, chiều cao chồi và trọng lượng tươi ở các nghiệm thức.

\subsubsection{Khảo sát ảnh hương của thời gian ngập} chìm đến khả năng tạo củ tù chồi tái sinh

Mẫu lily là cụm chồi mới phát sinh từ mẫu cấy được cắt bỏ lá, phần đế cũ, mẫu có chiều cao khoảng
$1 \mathrm{~cm}$ được đặt trong hệ thống TIS chứa môi trường MS bố sung saccharose: $30 \mathrm{~g} / \mathrm{L}$, nước dừa: 100 $\mathrm{ml} / \mathrm{L}$, than hoạt tính: $0,5 \mathrm{~g} / \mathrm{L}, \mathrm{BA}: 0,2 \mathrm{mg} / \mathrm{L}$, NAA: $1 \mathrm{mg} / \mathrm{L}$, nghiên cứu khả năng tạo củ từ chồi tái sinh ở các mức thời gian ngập chìm khác nhau (3 phút, 5 phút, 7 phút, 10 phút), thí nghiệm lặp 3 lần với 12 nghiệm thức, sau 8 tuần nuôi cấy quan sát và ghi nhận chỉ tiêu số củ/mẫu, số lá/củ, chiều cao chồi ở các nghiệm thức.

\subsubsection{Khảo sát ảnh hwởng của thời gian ngập chìm khả năng tạo rễ}

Mẫu lily là cụm chồi xanh, khỏe cắt bỏ lá được cấy vào hệ thống TIS chứa môi trường $\mathrm{MS}$ bổ sung saccharose: $30 \mathrm{~g} / \mathrm{L}$, nước dừa: $100 \mathrm{ml} / \mathrm{L}$, than hoạt tính: $0,5 \mathrm{~g} / \mathrm{L}, \mathrm{BA}: 0,2 \mathrm{mg} / \mathrm{L}, \mathrm{NAA}: 1 \mathrm{mg} / \mathrm{L}$ để nghiên cứu khả năng tạo rễ của cây in vitro thời gian ngập chìm (1 phút, 3 phút, 5 phút, 7 phút), thí nghiệm lặp 3 lần với 12 nghiệm thức, sau 8 tuần nuôi cấy quan sát và ghi nhận chỉ tiêu tỷ lệ tạo rễ, số rễ/cây, chiều dài rễ ở các nghiệm thức.

\subsection{Phương pháp thống kê và xử lý số liệu}

Các số liệu được phân tích ANOVA bằng phần mềm Minitab 16, các giá trị trung bình được kiểm định bằng phép thử Tukey ở mức ý nghĩa $95 \%$.

\section{KẾT QUẢ VÀ THẢO LUẬN}

\section{1. Ảnh hưởng của thời gian khử trùng mẫu bằng $\mathrm{HgCl}_{2} 1 \%$}

Khử trùng mẫu là giai đoạn quan trọng trong nuôi cấy in vitro, quá trình khử trùng đảm bảo tỷ lệ mẫu sống cao, tỷ lệ mẫu nhiễm thấp, mô cấy sinh trưởng tốt, chồi phát triển khỏe mạnh. $\mathrm{HgCl}_{2}$ là hóa chất có tính khử trùng mạnh được sử dụng phổ biến trong nuôi cấy in vitro. Vảy củ hoa lily là vật liệu tốt nhất cho quá trình tái sinh chồi. Do đó, vảy củ được sử dụng là nguồn mẫu đưa vào nuôi cấy. Kết quả nghiên cứu ảnh hưởng của thời gian khử trùng vảy củ hoa lily bằng $\mathrm{HgCl}_{2} \quad 1 \%$ sau 2 tuần nuôi cấy thể hiện ở Bảng 1.

\section{Bảng 1. Ảnh hưởng của thời gian xử lý $\mathrm{HgCl}_{2} \mathbf{1 \%}$}

\begin{tabular}{ccrrrr}
\hline TT & Ký hiệu mẫu & Thời gian (phút) & Tỷ lệ sống (\%) & Tỷ lệ chết (\%) & Tỷ lệ nhiễm (\%) \\
\hline 1 & MT1 & 7 & $40,53 \pm 2,11^{\mathrm{c}}$ & $10,05 \pm 1,07^{\mathrm{c}}$ & $49,42 \pm 2,23^{\mathrm{a}}$ \\
2 & MT2 & 9 & $79,52 \pm 1,51^{\mathrm{a}}$ & $0,43 \pm 0,45^{\mathrm{d}}$ & $20,04 \pm 1,95^{\mathrm{b}}$ \\
3 & MT3 & 11 & $50,87 \pm 2,47^{\mathrm{b}}$ & $39,20 \pm 3.11^{\mathrm{b}}$ & $9,92 \pm 1,09^{\mathrm{c}}$ \\
4 & MT4 & 13 & $19,40 \pm 1,65^{\mathrm{d}}$ & $71,04 \pm 2.96^{\mathrm{a}}$ & $9,55 \pm 1,74^{\mathrm{c}}$ \\
\hline
\end{tabular}

Ký hiệu: MT1, MT2, MT3, MT4 là trung bình mẫu của ba lần lặp lại ở các khoảng thòi gian 7, 9, 11, 13 phút. Giá trị là trung bình \pm sai số chuẩn của ba lần lặp lại. Các chũ cái theo sau giống nhau trong cùng một cột thì khác biệt không có ý nghĩa thống kê với kiểm định Tukey, mức ý nghĩa 95\%. 
Kết quả nghiên cứu được phân tích phương sai one-way ANOVA cho thấy có sự khác nhau giữa các nghiệm thức. Điều này chứng minh thời gian xử lý bằng $\mathrm{HgCl}_{2} 1 \%$ có ảnh hưởng đáng kể đến hiệu quả của quá trình khử trùng vảy củ hoa lily. Bảng 1 cho thấy xử lý mẫu trong thời gian 9 phút là khoảng thời gian tối ưu, kết quả này có sự khác biệt có ý nghĩa về mặt thống kê. Tỷ lệ mẫu sống đạt cao nhất $79,52 \%$, tỷ lệ mẫu chết $0,43 \%$, tỷ lệ nhiễ் $20,04 \%$ khi xử lý $\mathrm{HgCl}_{2}$ trong 9 phút. Thời gian khử trùng mẫu kéo dài hiệu quả khử trùng tăng, tuy nhiên mẫu bị tổn thương do đó tỷ lệ chết tăng. Ở công thức MT4 (13 phút) tỷ lệ nhiễm 9,55\%, tỷ lệ sống của mẫu giảm xuống còn $19,40 \%$. Kết quả nghiên cứu cho thấy tỷ lệ nhiễm giảm dần và tỷ lệ chết tăng dần khi thời gian xử lý mẫu càng kéo dài (Vũ Hoài Sâm, 2016). Như vậy, thời gian thích hợp nhất để khử trùng vảy củ hoa lily bằng $\mathrm{HgCl}_{2} 1 \%$ là 9 phút.

\section{2. Ảnh hưởng của $\mathrm{BA}$ và $\mathrm{NAA}$ đến khả năng tái sinh chồi}

Trong nuôi cấy mô tế bào thực vật, bên cạnh các chất cung cấp dinh dưỡng cho mô nuôi cấy, việc bổ sung một hoặc nhiều chất điều hòa sinh trưởng có vai trò đặc biệt quan trọng trong việc điều khiển sự phát sinh hình thái của mô nuôi cấy. Trong các chất điều hòa sinh trưởng, có hai nhóm được sử dụng nhiều là cytokinin và auxin. Nhiều nghiên cứu đã chứng minh khả năng tái sinh chồi đạt hiệu quả khi phối hợp hai nhóm cytokinin và auxin hơn là sử dụng một loại riêng lẻ. Quá trình tái sinh chồi phụ thuộc vào tỷ lệ cytokinin và auxin trong quá trình nuôi cấy (Mir et al., 2012).

Mẫu vảy củ hoa lily sạch nấm khuẩn được cấy trên hệ thống TIS chứa môi trường $\mathrm{MS}$ có bổ sung BA (cytokinin) và NAA (auxin) ở các tỷ lệ nồng độ khác nhau để tiến hành nghiên cứu khả năng tái sinh in vitro (Bui et al., 2017). Kết quả sau 8 tuần nuôi cấy được thể hiện ở Bảng 2.

Bảng 2. Ảnh hưởng của BA và NAA đến khả năng tái sinh chồi

\begin{tabular}{|c|c|c|c|c|c|c|}
\hline \multirow{2}{*}{ TT } & \multirow{2}{*}{ Ký hiệu mẫu } & \multicolumn{2}{|c|}{$\begin{array}{c}\text { Chất ĐHST } \\
\text { mg/l }\end{array}$} & \multirow{2}{*}{$\begin{array}{r}\text { Tỷ lệ tái sinh } \\
(\%)\end{array}$} & \multirow{2}{*}{$\begin{array}{r}\text { Chiều cao chồi } \\
(\mathbf{c m})\end{array}$} & \multirow{2}{*}{$\begin{array}{r}\text { Khối lượng tươi } \\
\text { (g) }\end{array}$} \\
\hline & & BA & NAA & & & \\
\hline 1 & MD1 & 1,0 & 0,5 & $15,05 \pm 1,127^{\mathrm{d}}$ & $2,46 \pm 0,427^{\mathrm{c}}$ & $19,19 \pm 0,373^{\mathrm{c}}$ \\
\hline 2 & MD2 & 1,5 & 0,5 & $44,71 \pm 1.476^{\mathrm{c}}$ & $3,41 \pm 0,344^{b}$ & $21,48 \pm 0,547^{b}$ \\
\hline 3 & MD3 & 2,0 & 0,5 & $83,89 \pm 1,433^{a}$ & $4,27 \pm 0,172^{\mathrm{a}}$ & $22,69 \pm 0,445^{\mathrm{a}}$ \\
\hline 4 & MD4 & 2,5 & 0,5 & $74,47 \pm 1,413^{\mathrm{b}}$ & $2,69 \pm 0,224^{\mathrm{bc}}$ & $19,95 \pm 0,170^{c}$ \\
\hline
\end{tabular}

Ký hiệu: MD1, MD2, MD3, MD4 là trung bình mẫu của ba lần lặp lại ở các nồng độ BA 1, 1, 5, 2, 0, 2, 5 mg/l. Giá trị là trung bình \pm sai số chuẩn của ba lần lặp lại. Các chũ cái theo sau giống nhau trong cùng một cột thì khác biệt không có ý nghĩa thống kê vói kiểm định Tukey, mưc ý nghĩa 95\%.

Nghiên cứu tác động của $\mathrm{BA}$ và NAA ở các tỷ lệ nồng độ khác nhau cho thấy sau 4 tuần mẫu cấy bắt đầu xuất hiện chồi xuất phát từ vảy củ. Kết quả nghiên cứu ghi nhận sau 8 tuần nuôi cấy được phân tích phương sai one-way ANOVA cho thây có sự khác nhau giữa các nghiệm thức. Điều này chứng minh tỷ lệ nồng độ $\mathrm{BA}$ và $\mathrm{NAA}$ có ảnh hưởng đáng kể đến kết quả của quá trình tái sinh chồi từ vảy củ hoa lily. Bảng 2 cho thấy tỷ lệ BA $2,0 \mathrm{mg} / \mathrm{L}$ và NAA $0,5 \mathrm{mg} / \mathrm{L}$ là tỷ lệ tối ưu, kết quả này có sự khác biệt có ý nghĩa về mặt thống kê, đặc biệt ở chỉ tiêu tỷ lệ tái sinh chồi. Khả năng tái sinh chồi đạt cao nhất $83,89 \%$, chiều cao chồi đạt $4,27 \mathrm{~cm}$, khối lượng tươi đạt 22,69 g dưới sự tác động của $\mathrm{BA}$ và NAA kích thích quá trình. Tiếp tục tăng nồng độ $\mathrm{BA}$, tỷ lệ tái sinh chồi có xu hướng giảm, điều này cho thấy hàm lượng $\mathrm{BA}$ cao đã ức chế quá trình sinh trưởng và phát triển của mẫu cấy. Kết quả nghiên cứu cho thấy khả năng tái sinh của vật liệu cấy phụ thuộc vào nồng độ, tỷ lệ hàm lượng giữa các chất điều hòa sinh trưởng (Nguyễn Thị Phương Thảo và ctv., 2011). Như vậy, mẫu cấy có khả năng tái sinh chồi in vitro từ vảy củ trên môi trường MS đạt kết quả tối ưu khi bổ sung $2,0 \mathrm{mg} / \mathrm{L}$ BA và $0,5 \mathrm{mg} / \mathrm{L}$ NAA, trên hệ thống TIS, chồi phát triển nhanh, năng suất cao, phẩm chất tốt.

\section{3. Ảnh hưởng thời gian ngập chìm đến khả năng tạo củ từ chồi tái sinh}

Cụm chồi lily được cắt bỏ phần đế cũ đặt trong hệ thống TIS với các mức thời gian ngập chìm khác nhau ( 3 phút, 5 phút, 7 phút, 10 phút) để tiến hành nghiên cứu ảnh hưởng của thời gian ngập chìm đến khả năng tạo củ từ chồi tái sinh. Kết quả sau 8 tuần nuôi cấy được thể hiện ở Bảng 3. 
Bảng 3. Ảnh hưởng của thời gian ngập chìm đến khả năng tạo củ từ chồi tái sinh

\begin{tabular}{cccrrr}
\hline TT & Ký hiệu mẫu & $\begin{array}{c}\text { Thời gian } \\
\text { Ngập chìm (phút) }\end{array}$ & Số củ/mẫu (củ) & Số lá/củ (lá) & Chiều cao chồi (cm) \\
\hline 1 & MC1 & 3 & $1,84 \pm 0,291^{\mathrm{b}}$ & $3,42 \pm 0,166^{\mathrm{ab}}$ & $4,76 \pm 0,235^{\mathrm{bc}}$ \\
2 & MC2 & 5 & $3,72 \pm 0,142^{\mathrm{a}}$ & $4,49 \pm 0,336^{\mathrm{a}}$ & $6,37 \pm 0,255^{\mathrm{a}}$ \\
3 & MC3 & 7 & $2,38 \pm 0,276^{\mathrm{b}}$ & $3,31 \pm 0,217^{\mathrm{b}}$ & $5,51 \pm 0,321^{\mathrm{b}}$ \\
4 & MC4 & 10 & $2,09 \pm 0,291^{\mathrm{b}}$ & $3,57 \pm 0,390^{\mathrm{b}}$ & $4,52 \pm 0,420^{\mathrm{c}}$ \\
\hline
\end{tabular}

Ký hiệu: MC1, MC2, MC3, MC4 là trung bình mẫu của ba lần lặp lại ở mức thời gian ngập chìm 3, 5, 7, 10 phút. Giá trị là trung bình \pm sai số chuẩn của ba lần lặp lại. Các chũ cái theo sau giống nhau trong cùng một cột thì khác biệt không có ý nghĩa thống kê với kiểm định Tukey, mức ý nghĩa 95\%.

Các nghiệm thức có sự khác biệt về số củ, số lá/củ và chiều cao chồi. Kết quả nghiên cứu ghi nhận sau 8 tuần nuôi cấy được phân tích phương sai oneway ANOVA cho thấy có sự khác nhau giữa các nghiệm thức. Điều này chứng minh thời gian ngập chìm có ảnh hưởng đáng kể đến khả năng tạo củ từ chồi tái sinh. Bảng 3 cho thấy thời gian ngập chìm 5 phút là thời gian tối ưu, các chỉ tiêu số củ/mẫu, số lá/củ và chiều cao chồi giữa các nghiệm thức có sự khác biệt tương đối rõ rệt. Nghiệm thức $\mathrm{MC} 2$ cho kết quả cao nhất khi thời gian ngập chìm 5 phút, số củ đạt $3,72 /$ mẫu, số lá đạt $4,49 /$ củ, chiều cao chồi đạt $6,37 \mathrm{~cm}$. Càng kéo dài thời gian ngập chìm cho thấy số củ, số lá, chiều cao chồi có xu hướng giảm. Điều này cho thấy thời gian ngập chìm ảnh hưởng đến khả năng tạo củ từ chồi tái sinh. Khi thời gian ngập chìm $\mathrm{MC} 1$ ngắn lượng chất dinh dưỡng cung cấp chưa đủ để củ hình thành và phát triển. Tuy nhiên, khi thời gian ngập chìm kéo dài lâu mẫu cấy có hiện tượng trương nước, các mẫu cấy ở nghiệm thức MC3, MC4 có tốc độ phát triển chậm lại. Như vậy, tần suất ngập 5 phút, chu kỳ ngập 6 giờ là thời gian thích hợp để tạo củ lily từ chồi tái sinh. Trong hệ thống TIS, môi trường không khí luôn có sự trao đổi giữa bên trong và bên ngoài thông qua hệ thống bơm và các màng lọc, do được sinh trưởng trong môi trường thoáng khí nên mẫu cấy phát triển tốt (Cung Hoàng Phi Phượng, 2007).

\section{4. Ảnh hưởng của thời gian ngập chìm đến khả năng tạo rễ}

Để tạo bộ rễ khỏe mạnh chuẩn bị tốt cho giai đoạn ra cây ngoài vườn, mẫu sau khi được nuôi cấy trong môi trường tạo củ, tiếp tục nuôi cấy trên hệ thống TIS với các mức thời gian ngập chìm khác nhau (1 phút, 3 phút, 5 phút, 7 phút) để tiến hành nghiên cứu ảnh hưởng của thời gian ngập chìm đến khả năng tạo rễ của cây. Kết quả sau 8 tuần nuôi cấy được thể hiện ở Bảng 4.

Bảng 4. Ảnh hưởng của thời gian ngập chìm đến khả năng tạo rễ

\begin{tabular}{cccccc}
\hline \multirow{2}{*}{ TT } & \multirow{2}{*}{ Ký hiệu mẫu } & \multicolumn{2}{c}{ Thời gian } \\
Ngập chìm (phút) & TL tạo rễ $(\%)$ & Số rễ/cây (Rễ) & Chiều dài rễ (cm) \\
\hline 1 & MR1 & 1 & $56,11 \pm 1,626^{\mathrm{d}}$ & $2,71 \pm 0,298^{\mathrm{c}}$ & $2,61 \pm 0,281^{\mathrm{c}}$ \\
2 & MR2 & 3 & $86,74 \pm 1,834^{\mathrm{a}}$ & $4,52 \pm 0,373^{\mathrm{a}}$ & $4,81 \pm 0,185^{\mathrm{a}}$ \\
3 & MR3 & 5 & $83,63 \pm 1,403^{\mathrm{b}}$ & $3,62 \pm 0,356^{\mathrm{b}}$ & $3,71 \pm 0,379^{\mathrm{b}}$ \\
4 & MR4 & 7 & $78,24 \pm 1,835^{\mathrm{c}}$ & $2,99 \pm 0,308^{\mathrm{bc}}$ & $3,11 \pm 0,193^{\mathrm{bc}}$ \\
\hline
\end{tabular}

Ký hiệu: MR1, MR2, MR3, MR4 là trung bình mẫu của ba lần lạ̣p lại ở múc thòi gian ngập chìm 1, 3, 5, 7 phút. Giá trị là trung bình \pm sai số chuẩn của ba làn lập lại. Các chũ cái theo sau giống nhau trong cùng một cột thì khác biệt không có ý nghĩa thống kê với kiểm định Tukey, mức ý nghĩa 95\%.

Cây được nuôi cấy trong hệ thống TIS có tốc độ sinh trưởng nhanh, hệ rễ phát triển, thân to khỏe, lá xanh mướt, cụm chồi theo thời gian chỉ gia tăng về số lượng rễ, kích thước củ, chiều cao chồi. Ở các nghiệm thức có sự khác biệt về tỉ lệ tạo rễ, số rễ/cây và chiều dài của rễ. Kết quả nghiên cứu được phân tích phương sai one-way ANOVA cho thây có sự khác nhau giữa các nghiệm thức. Điều này chứng minh thời gian ngập chìm có ảnh hưởng đáng kể đến khả năng tạo rễ của cây. Bảng 4 cho thấy thời gian ngập chìm 3 phút là thời gian tối ưu, kết quả này có sự khác biệt có ý nghĩa về mặt thống kê, đặc biệt ở chỉ tiêu tỷ lệ tạo rễ. Nghiệm thức MR2 cho tỷ lệ tạo rễ đạt $86,74 \%$, số rễ đạt 4,52/cây, chiều dài rễ đạt $4,81 \mathrm{~cm}$ khi thời gian ngập chìm 3 phút. Càng kéo dài thời gian ngập chìm cho thấy số rễ, chiều dài rễ không tăng. Điều này cho thấy thời gian ngập chìm ảnh hưởng đến khả năng hình thành rễ. Khi thời gian ngập chìm kéo dài mẫu cấy bị ngập trong môi trường lâu gây thiếu khí, làm chậm quá trình phát triển của rễ (Phạm Thị Thùy Trang \& Bùi Thị Ngọc Hân, 2017). Như vậy, Tần suất ngập chìm tối ưu 3 phút 
với chu kỳ ngập 6 giờ cung cấp hàm lượng chất dinh dưỡng vừa đủ để bộ rễ hình thành và phát triển tốt. Kết thúc quá trình nuôi cấy, cây con đạt tiêu chuẩn dạng củ, đạt 3-5 rễ, chiều dài rễ đạt $3-5 \mathrm{~cm}$, được chuyển sang giai đoạn huấn luyện cây ngoài vườn ươm.

\section{KẾT LUẬN}

Nghiên cứu đã xây dựng thành công quy trình nuôi cấy cây hoa lily trên hệ thống ngập chìm tạm thời. Vật liệu ban đầu được sử dụng là vẩy củ hoa lily được khử trùng bề mặt bằng dung dịch $\mathrm{HgCl}_{2}$ $1 \%$ trong thời gian 9 phút, mẫu được tái sinh trong môi trường MS có bổ sung chất kích thích sinh trưởng BA 2 mg/L, NAA $0,5 \mathrm{mg} / \mathrm{L}$. Tần suất ngập chìm 5 phút với chu kỳ ngập 6 giờ là thời gian thích hợp để tạo củ lily, tần suất ngập chìm 3 phút với chu kỳ ngập 6 giờ là thời gian thích hợp để tạo rễ lily trên hệ thống ngập chìm. Kết quả nghiên cứu cho thấy hệ thống nuôi cấy ngập chìm tạm thời thích hợp nhân giống in vitro ở quy mô công nghiệp cho năng suất cao, tiết kiệm được chi phí nhân công, tỷ lệ nhiễm thấp.

\section{TÀI LIỆU THAM KHẢO}

Barbara, R. \& Marco, S. (2005). The Temporary Immersion System (T.I.S.) for the Improvement of Micropropagation of Ornamental Plants. V International Symposium on New Floricultural Crops, 683, $445-454$.

Bui, T. T. H., Dong, H. G. \& Bui, V. T.. (2017). Optimisation of an in vitro propagation protocol for a valuable lily (Lilium spp). Journal of forestry science and technology, 5, 18-25.

Cung Hoàng Phi Phượng. (2007). Bước đầu úng dụng hẹ thống nuôi cấy ngập chìm tạm thời trong nhân giống lan Hồ điệp lai - Phalaenopsis hybrid. Hội nghị khoa học "Công nghệ sinh học thực vật trong công tác nhân giống và chọn tạo giống hoa”. NXB Nông nghiệp TP Hồ Chí Minh.
Đặng Văn Đông, Nguyễn Thị Thanh Tuyền, Trịnh Khắc Quang \& Lê Thị Thu Hương. (2010). Úng dung công nghẹ sinh hoc trong chon tạo và nhân giống cây hoa Lily, Loa Kèn. NXB Hà Nội.

Mir, J. I., Ahmed N., Itoo H., Sheikh, M. A., Rizwan, R. \& Shabir, H. W. (2012). In vitro propagation of Lilium (Lilium longiflorum), Indian Journal of Agricultural Sciences, 82 (5), 455-458.

Murashige, T. \& Skoog R. (1962). A revised medium for rapid growth and bioassays with tobacco tissue cultures. Physiol Plant, 15, 473-479.

Nguyễn Thị Phương Thảo, Nông Thị Huệ, Vũ Quang Khánh \& Nguyễn Hữu Cường. (2011). Nghiên cứu nhân nhanh in vitro cây hoa loa kèn (Lilium pollanel Gapnep). Tap chí Khoa hoc và phát triển, 9(5), 743-750.

Nguyễn Văn Tỉnh, Nguyễn Xuân Kết, Đặng Văn Đông \& Hoàng Minh Tấn. (2013). Kết quả nghiên cứu sản xuất củ hoa lily bằng phương pháp tách vảy củ tại Miền Bắc Việt Nam. Tạp chi Khoa hoc và Phát triển 2013, 11(8), 1109 - 1117.

Paula, W. M. (2012). The status of temporary immersion system (TIS) technology for plant micropropagation. African Journal of Biotechnology, 11(76), 14025-14035.

Phạm Thị Thùy Trang \& Bùi Thị Ngọc Hân. (2017). Nghiên cứu ảnh hưởng của chất điều hòa sinh trưởng đến quá trình nhân giống lan hồ điệp (phalaenopsis amabilis) trên hệ thống ngập chìm tạm thời. Tạp chí Khoa học và Công nghệ Đại học Đà Nẫng, 2(111), 143-147.

Vidal, N., Blanco, B. \& Cuenca B. (2015). A temporary immersion system for micropropagation of axillary shoots of hybrid chestnut. Plant Cell Tiss Organ Cult 123, 229-243.

Vũ Hoài Sâm. (2016). Nghiên cứu nhân giống in vitro cây bách hợp (Lilium Brownii fe brown). Tạp chí Công nghẹ Sinh hoc, 14(1), 121-129. 